\title{
Reinforcement of logical-mathematical reasoning in new Engineering students to reduce failing and dropout rates
}

\section{Fortalecimiento del razonamiento lógico y matemático en estudiantes de nuevo ingreso de las carreras de Ingeniería para disminuir los índices de reprobación y deserción}

\author{
REYES-DE LOS SANTOS, Iyeliz†** \\ Universidad Tecnológica del Valle de Toluca. Carretera del departamento del D.F. km. 7. Santa María Atarasquillo Lerma, \\ Estado de México. C.P. 52044
}

ID $1^{\text {st }}$ Author: Iyeliz, Reyes-De Los Santos / ORC ID: 0000-0003-4191-2332, CVU CONACYT ID: 269534

DOI: 10.35429/JHEW.2019.5.3.1.7

Received September 11, 2019; Accepted December 20, 2019

\begin{abstract}
The paper exposes the results of an experiment carried out at the Universidad Tecnológica del Valle de Toluca, in the major of Information and Communication Technologies. It consisted of strengthening or developing the logical and mathematical reasoning in new students to reduce the failing and dropout rates. A sample of thirty students was selected, to whom the proposed strategy was applied, a course with exercises and activities to strengthen or develop logical and mathematical reasoning; This workshop was designed according to the cognitive functions and mental operations established by Reuven Feuerstein in his Theory of Cognitive Modifiability. Before and after the workshop, a test was proposed by the CENEVAL (Centro Nacional de Evaluación para la Educación Superior) in an interactive guide for applicants taking the entrance exam for higher level education, afterwards, the failing and dropout rates were calculated, both for the pilot group and for the rest of the students who did not participate in the experiment. The hypothesis was not completely verified, since only one of the analyzed indexes was reduced, interesting results and some recommendations as future work are also addressed.
\end{abstract}

Logical and mathematical reasoning, Desertion, Higher education

\begin{abstract}
Resumen
El trabajo expone los resultados de un experimento que se realizó en la Universidad Tecnológica del Valle de Toluca (UTVT), dentro de la carrera de Tecnologías de la Información y Comunicación (TIC). Consiste en fortalecer o desarrollar el razonamiento lógico y matemático en estudiantes de nuevo ingreso para disminuir los índices de reprobación y deserción. Se seleccionó una muestra de treinta estudiantes, a los que se les aplicó la estrategia propuesta, un taller de ejercicios y actividades para fortalecer o desarrollar el razonamiento lógico y matemático; dicho taller fue diseñado de acuerdo a las funciones cognitivas $y$ operaciones mentales que estableció Reuven Feuerstein en su Teoría de Modificabilidad Cognitiva. Antes y después del taller se aplicó una prueba que propuso el CENEVAL (Centro Nacional de Evaluación para la Educación Superior) en una guía interactiva para aspirantes a presentar el examen de admisión para el nivel superior, posteriormente, se calcularon los índices de reprobación y deserción tanto del grupo piloto como del resto de los estudiantes que no participaron en el experimento (grupo de control). La hipótesis no fue aprobada completamente, ya que sólo uno de los índices analizados se redujo, de los resultados obtenidos se abordan interesantes conclusiones y algunas recomendaciones como trabajo futuro.
\end{abstract}

Razonamiento lógico y matemático, Deserción, Educación superior

Citation: REYES-DE LOS SANTOS, Iyeliz. Reinforcement of logical-mathematical reasoning in new Engineering students to reduce failing and dropout rates. Journal Health, Education and Welfare. 2019. 3-5: 1-7

$\dagger$ Researcher contributing first author. 


\section{Introduction}

For several years, the reasons for dropping out and school failure in Mexico have been studied, especially in higher levels of education, where numbers are higher compared to the basic level. It is necessary to analyze and attack immediately the reasons for this problem. In Mexico, there are many studies that report this situation statistically but few propose viable, permanent and significant solutions.

The entry profile of all Engineering degrees requires basic knowledge of Mathematics and proficiency in logical and mathematical reasoning; subjects that are closely linked to the capacities of abstraction, analysis, synthesis, organization and problem solving. The absence of these abilities hinders the continuity of studies in these majors. This difficulty is reflected in the failing and dropout rates of any educational entity.

At the Technological University of Valle de Toluca (UTVT), particularly in the Information and Communication Technologies major, the failing and dropout rates have exceeded the permitted standard levels, so there is a need to seek and implement solutions to reduce these indices.

The efforts exerted so far include advice, tutoring and the application of different final tests in order to achieve the lowest number of failing students. It is considered that the actions carried out so far have not attacked the root of the problem.

The proposal presented in this work is a strategy to develop and strengthen an indispensable skill that future professionals in the area of Engineering must possess to successfully achieve the culmination of their studies: logical and mathematical reasoning.

The workshop was designed with activities and exercises according to the cognitive functions and mental operations that Feuerstein raised in his theory of Cognitive Modifiability. To measure the effectiveness of this workshop, we used a test proposed by CENEVAL (National Center for Evaluation for Higher Education, for its acronym in Spanish) in an interactive guide for applicants taking the admission exam for the higher level, which was applied before and after said workshop.
Among the variables found are the level of logical and mathematical reasoning of the students, the drop-out and failing rates. The experiment was carried out on a pilot group of thirty students who received the proposed strategy, for the selection we used simple random sampling, since all individuals had the same probability of being chosen and no subject influenced on the selection of another.

The process of a quantitative investigation was followed with its respective quantitative data analysis, which allowed answering the research question. From the results obtained, interesting conclusions are addressed, some recommendations as future work, as well as a discussion that links the projects carried out previously with this work.

\section{Hypothesis}

Will the development and / or strengthening of the logical and mathematical reasoning in new students of engineering majors reduce the failing and dropout rates?

\section{General Objective}

Designing a program or workshop for the strengthening of logical and mathematical reasoning in new students of engineering majors, which includes a set of activities or exercises.

\section{Specific Objectives}

Preparing a test that allows the measurement of the logical and mathematical reasoning of the new students of engineering majors.

- Investigating techniques and tests for the development or reinforcement of logical and mathematical thinking in adults.

Defining an educational strategy through a workshop or program for the strengthening of logical-mathematical reasoning in university students of engineering majors.

- Conducting an experiment for the implementation of the proposed strategy and determine its effectiveness. 


\section{Background}

Acosta Triviño, Rivera Acevedo \& Acosta Triviño (2009) proposed a workshop for the development of mathematical logical thinking in order to improve the teaching of Mathematics at the higher level education. This was raised by the Foundation for Higher Education San Mateo de Colombia. They conducted an analysis in which they detected that the majority of Colombian students lack a good formation and development of logical-mathematical thinking when they enroll in universities and it is even a weakness of many professionals already graduated.

The program applies the theory of Cognitive Modifiability of Dr. Feuerstein, which is based on the principle that: "The human organism is an open system that in its evolution acquired the propensity to modify itself, as long as there is a human act mediator." This theory considers that there are no irreversible conditions that cannot be managed and treated (Acosta et al., 2009).

Reuven Feuerstein, is a Romanian psychologist who proposed the theory of Cognitive Modifiability, in which he states that intelligence is modifiable and focuses on the development of cognitive functions and mental operations in order to increase or modify them if necessary. These functions are:

- Identification: ability to attribute meaning to a fact or situation.

Evocation: ability to remember a previous experience.

Comparison: ability to contrast two or more elements establishing similarities and differences.

- $\quad$ Analysis: ability to break down the whole into its constituent elements.

Synthesis: ability to integrate elements, relationships, properties or parts to form new and significant totalities.

Classification: Ability to group elements into classes and subclasses according to one or more well-defined criteria or attributes.

- Mental representation: ability to use signifiers to mentally evoke reality.

Deduction: it implies logical inference from what is already known, deductions can be made from generalizations or explicit principles to identify specific consequences.
- Induction: it is the reasoning generated from the constant observation between phenomena, or the objects of knowledge to look for essential relationships. It is important to discover laws, principles or generalizations.

- Divergent reasoning: ability to produce different and creative ideas or solutions to the problems posed.

- Hypothetical reasoning: ability to mentally rehearse various options for interpretation and resolution of a problem.

- Inferential reasoning: ability to predict or generalize the behavior of facts or phenomena from particular situations or experiences.

\section{Methodology}

The methodology proposed describes the type of research design, the stages of the experiment, the description of the sample and the instruments used. This methodological proposal contributes to the specification of a strategy for conducting an experimental research in an educational environment, in which a problem, a hypothesis and an experiment are presented, where the main actors are the students; important results and conclusions can be obtained in order to improve or strengthen educational quality.

The type of Research Design used was Experimental, since an independent variable was manipulated to analyze the consequences on two other dependent variables. And particularly, the subtype of the Experimental Research Design used was the Pure or True, because two groups were created, one that received the experimental treatment and another (the rest of the population) that was the control group, which did not receive the treatment. The experimental or pilot group was chosen randomly, a pre-test, a treatment and a post-test were applied. In the end, the results were analyzed and compared.

The experiment consisted of four stages: a pre-test, the application of the proposed strategy for the development or strengthening of logical-mathematical reasoning (workshop), the post-test, and finally the calculation of dropout and failing rates, see Figure 1. 


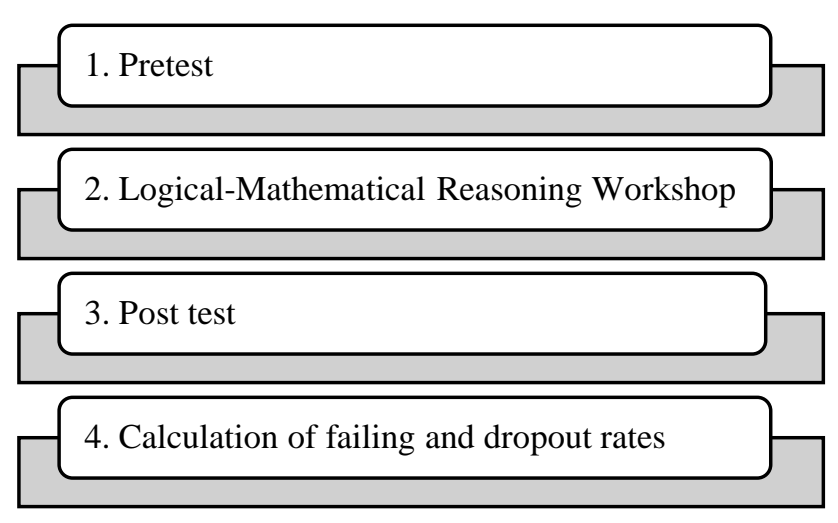

Figura 1 Etapas del experimento

The first activity consisted of taking a group of new students from the ICT Engineering major, this group received, in addition to their curriculum, a workshop that allowed increasing their levels of logical- mathematical reasoning. The other group, the rest of the population (control group) continued with their usual study plan or curriculum.

\section{The sample}

The experiment was carried out at the UTVT in the ICT Engineering major.

A group of 30 students was selected, which corresponds to approximately $20 \%$ of total students enrolling in the ICT Engineering major at UTVT, annually. The students in the sample group were listed by assigning each member an identifier. It should be mentioned that the sample size was reduced to $80 \%$ since 6 students dropped out before the end of the experiment. The total population size before starting the experiment was 143, after the experiment it was reduced to 116 .

Simple random sampling was used, since all individuals were equally likely to be chosen and no subject influenced the selection of another.

\section{Instruments applied}

The experiment consisted of four stages, in each of them different types of instruments and mechanisms were defined for obtaining the data.

\section{Instrument for the Pre-test and Post-test}

The admission process at the Technological University of Valle de Toluca begins in May, applying the New National Admission Exam for higher education (EXANI-II), which is applied by the National Center for Evaluation for Higher Education (CENEVAL). The EXANI-II evaluates the knowledge and skills essential for entering higher education and is comprised of two tests (CENEVAL, 2018):

a. Selection: mandatory, which includes questions that measure verbal, mathematical and new technology skills.

b. Diagnosis: optional, with knowledge of five areas that reflect the major profile the individual wants to study (Administrative Sciences, Agricultural Sciences, Health Sciences, Natural and Exact Sciences and Social Sciences).

CENEVAL distributes an interactive digital guide of the EXANI-II exam for free, where the student can prepare for the admission exam through a series of exercises, it also includes a final mock exam that can be applied as an essay before the real exam, immediately reporting the results obtained, see Figure 2.

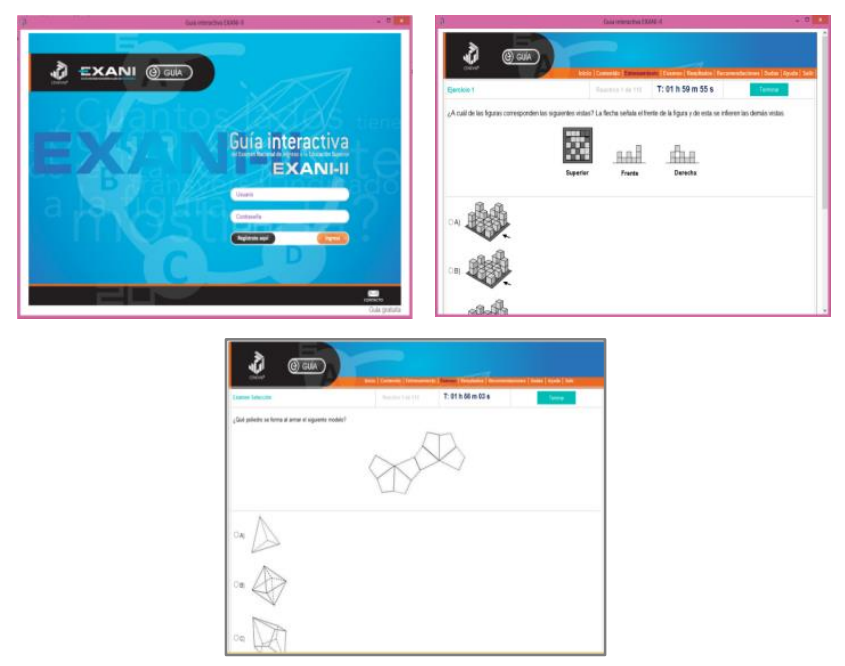

Figure 2 EXANI-II interactive guide

In the experiment, the test proposed in the interactive guide described above was applied to measure the level of logical and mathematical reasoning of the pilot group. This exam was chosen as an instrument for data collection because of the reliability it projects as it is endorsed by CENEVAL, an agency that assesses knowledge and skills for enrollment to higher level education. 
The purpose was to obtain a parameter that indicates the level of logical and mathematical reasoning of the group, before and after (pre-test and post-test) carrying out the workshop; Although this was not the end of the project, this rating served to measure the effectiveness of the proposed strategy.

\section{Instrument for calculating dropout and} failing rates.

The objective of the work is to demonstrate that increasing the level of logical and mathematical reasoning will decrease the dropout and failing rates, which are calculated officially and periodically at the end of each four-month period and annually, using the following formulas:

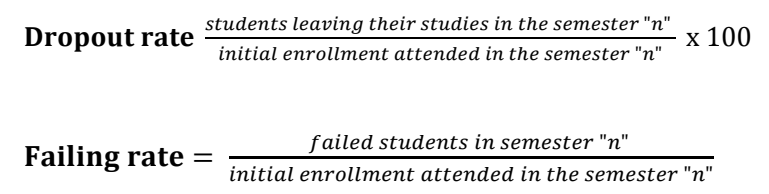

These formulas were defined by the General Coordination of Technological and Polytechnic Universities (CGUTyP), for the calculation of these indexes every four months and every year in all the educational programs that it coordinates.

\section{Instrument for the proposed strategy}

Considering the cognitive functions and mental operations that Reuven Feuerstein established in his theory of Cognitive Modifiability, the exercises that allow their development or strengthening were investigated. The result of this research is a series of activities addressed in the workshop as part of the proposed strategy.

\section{Results}

In order to know if the workshop was effective in developing or strengthening the level of logical and mathematical reasoning in new students of the engineering majors, the parametric comparison test of two related samples, $t$ student, was used. To apply this calculation it was necessary to define a null hypothesis:

Ho $=$ There is no difference in the level of logical and mathematical reasoning of students between the start and the end of the measurement.
The calculation was made with the Minitab tool, obtaining the following results:

The $t$-value is -2.78 and the $p$-value is $0.011, p$ is a probability that measures the evidence against a null hypothesis. A smaller $p$ value provides stronger evidence against the null hypothesis. The level of significance that was used was 0.05 , since it is the one normally established in social sciences.

When the value of $p$ is less than or equal to the level of significance, the decision is to reject the null hypothesis. This concludes that the workshop for the development and strengthening of logical and mathematical reasoning was effective.

The hypothesis also suggests that dropout and failing rates will be reduced; these rates were calculated for both the sample group and the control group (rest of the population).

The results obtained from the experiment were the following: after applying the workshop to the sample, $56.66 \%$ of the students increased their level of logical and mathematical reasoning, $13.33 \%$ maintained it and $10.0 \%$ decreased it, according to the post-test. $20 \%$ dropped out before applying this test (Figure 3).

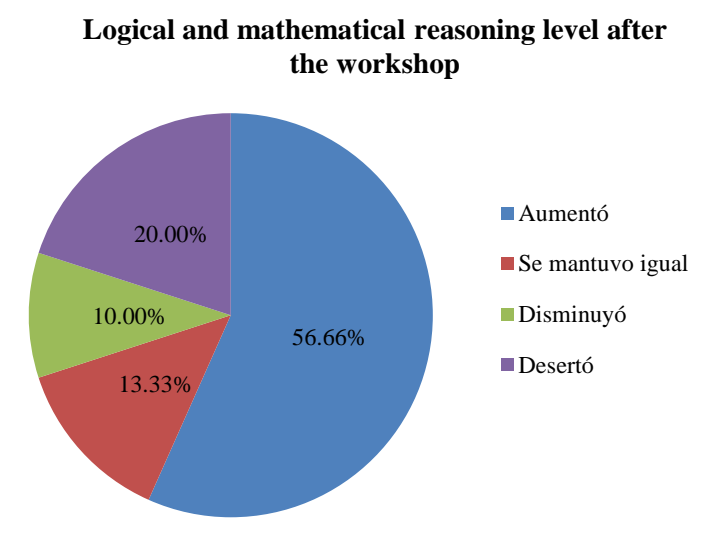

Figure 3 Logical and mathematical reasoning level after the workshop

Dropout and failing rates were calculated for both the pilot group and the control group and the following results were obtained, applying formulas 1 and 2 .

In the pilot group:

Dropout index $=\frac{6}{30} \times 100=20.0 \%$

Failing index $=\frac{0}{30} x 100=0.0 \%$ 
In the control group:

Dropout index $=\frac{10}{113} \times 100=8.85 \%$
Failing index $=\frac{11}{113} \times 100=9.73 \%$

The failing rate for the pilot group was $0 \%$, while in the control group was $9.73 \%$. The dropout rate was $20 \%$ in the first group and $8.85 \%$ in the second group (Figure 4 ).

Failure and dropout rates

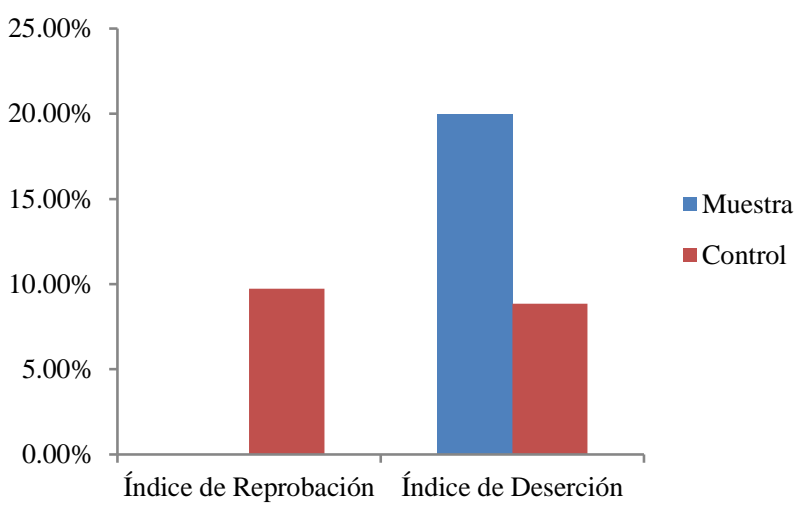

Figure 4 Failure and dropout rates

\section{Conclusions}

The research developed allowed us to know that the failure and the low level of academic achievement are the main reasons for dropping out, especially in the first two periods of higher level education institutions.

For the students of the engineering majors, the desirable profile describes that a student must possess abilities of analysis, abstraction and synthesis, skills that are obtained through the development of mathematical and logical reasoning. This paper presented the hypothesis that through the strengthening of logical and mathematical reasoning in new students of these careers, the rates of failure and dropout may be reduced.

The method established developing a pure experiment, selecting a sample of students to apply the strategy. A test that evaluated the skills of logical and mathematical reasoning was implemented, dropout and failing rates were calculated to the pilot group and compared with the rest of the students who did not participate in the experiment. The pilot group was expected to obtain lower values and thus prove the hypothesis. However, only the failing rate decreased, responding to the research question.
It is concluded that the strengthening or development of logical-mathematical reasoning helped to only decrease the failing rate, therefore the hypothesis was rejected. However, the objectives were achieved by defining an educational strategy through a workshop for the strengthening of logical-mathematical reasoning in university students of engineering majors, particularly for the ICT Engineering major of the UTVT.

\section{Recommendations and future work}

Student dropout is a problem that has economic and social repercussions in a country, so it is necessary to analyze and address immediately the reasons for this problem. In Mexico, there are many studies that report this situation statistically, but few propose viable and significant solutions. According to the results obtained in this investigation, the following recommendations are suggested:

1. Implementation of the workshop for new students of the engineering major of the Technological University of Valle de Toluca, to reduce the failing rates.

2. The workshop may be proposed for groups of students who have low levels of logical and mathematical reasoning, detected at the beginning of the school periods, every semester or quarter, according to the educational plan.

3. Proposing the use of this workshop in the upper middle levels of education for those students who wish to study an engineering degree.

4. Sharing research results to other areas and universities, to implement the strategy in other types of majors.

5. Preparing tests that measure each of the cognitive functions and mental operations proposed by Reuven Feuerstein, and according to the results, attacking only those that are necessary to develop or strengthen, this, for future research that addresses the issue discussed. 


\section{Referencias}

A. de Sánchez, M. (2007). Desarrollo de Habilidades del Pensamiento, Procesos Básicos del Pensamiento. Mexico: Trillas, ISBN 9682452686. 2007.

Acosta T. G., Rivera A. L., Acosta T. M. (2009). Desarrollo del Pensamiento Lógico Matemático. Fundación para la Educación Superior San Mateo. ISBN. 978-958-98600-4-5. Bogota, Colombia.

$\mathrm{Cu}$, B. G. (2005). "El impacto de la escuela de procedencia del nivel medio superior en el desempeño de los alumnos en el nivel universitario", Revista Electrónica Iberoamericana sobre Calidad, Eficacia y Cambio en Educación, volumen 3(1). Retrieved from:

http://redalyc.uaemex.mx/redalyc/pdf/551/5513 0171.pdf.

Leyva, L. L. y Proenza, G. Y. (2006) (2006). Reflexiones sobre la calidad del aprendizaje y de las competencias matemáticas, Revista Iberoamericana de Educación,1(41), pp. 16815653.

Rodríguez L. J., Leyva, P. M. (2007). La deserción escolar universitaria. La experiencia de la UAM. Entre el déficit de la oferta educativa superior y las dificultades de la retención escolar. El Cotidiano, volumen 22(núm. 142), pp. 98-111. Retrieved from http://www.redalyc.org/pdf/325/32514212.pdf.

Rojas, H. (27 marzo, 2014). Combatir la pobreza desde la educación media superior. Educación Futura. Retrieved from http://www.educacionfutura.org/combatirpobreza-desde-la-educacion-media-superior

Zabala, A., Arnau, L.. Evaluar competencias es evaluar procesos en la resolución de situaciones problema. 11 Ideas clave: como aprender y enseñar competencias. Cuarta edición, 2008. Barcelona, Spain. ISBN: 978-84-7827-500-7. 